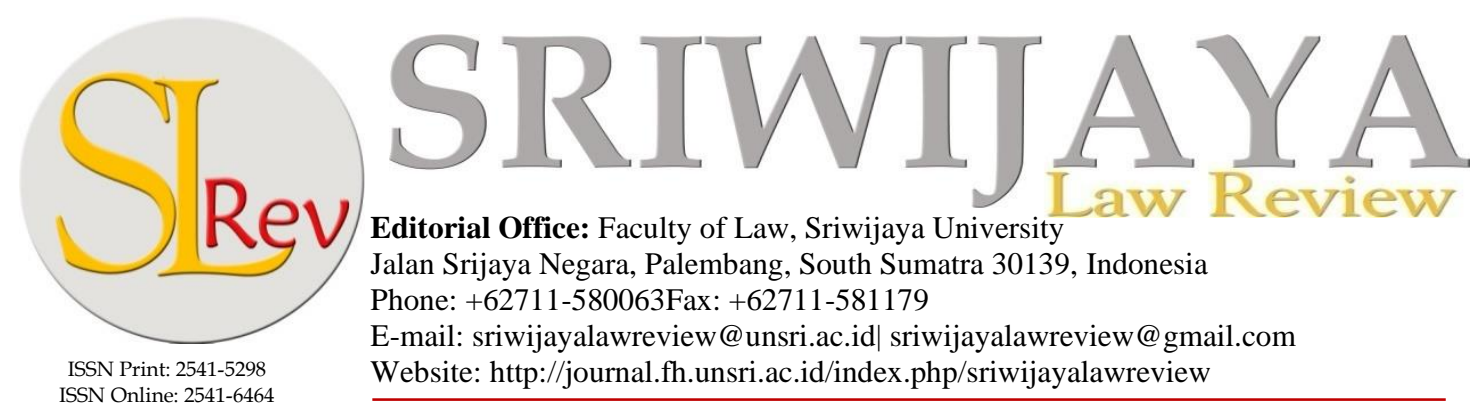

\title{
Constitutional Rules on Waqf and Fiscal Policy Outcomes
}

\author{
Abdul Ghafar Ismail ${ }^{\mathrm{a}^{*}}$ and Wahyu Ario Pratomo ${ }^{\mathrm{b}}$ \\ $a^{*}$ Corresponding author. Faculty of Economics and Muamalat, Universiti Sains Islam Malaysia, Negeri Sembilan, \\ Malaysia. Email: agibab62@gmail.com \\ b Faculty of Economics and Business, Universitas Sumatera Utara, Medan, Indonesia. Email: \\ wahyuario@gmail.com
}

\begin{tabular}{|c|c|}
\hline Article & Abstract \\
\hline 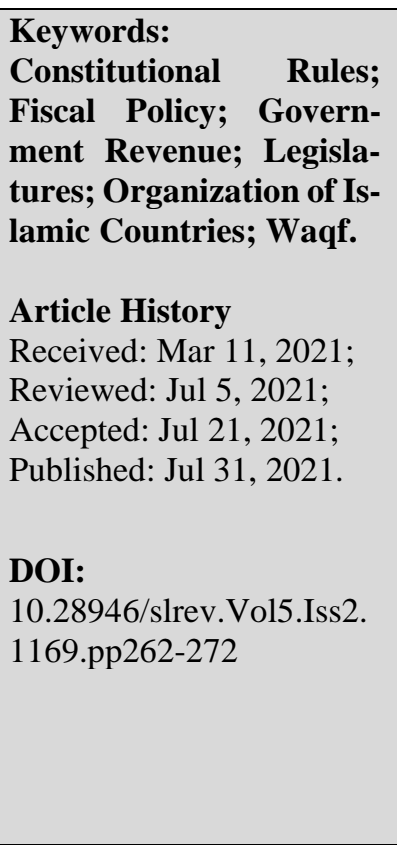 & $\begin{array}{l}\text { Fiscal policy, inter alia, looks at the list of government revenues. The consti- } \\
\text { tutional rules provide guidance on the list of revenues. However, the previous } \\
\text { studies find that waqf is not considered as part of government revenues. In this } \\
\text { study, we argue that waqf brings in a new list of government revenues. To } \\
\text { prove this point, we select a sample of fifty-seven countries under the Organ- } \\
\text { ization of Islamic Countries. The constitution of each country is investigated } \\
\text { by using content analysis. The study uses a combination of several keywords, } \\
\text { namely "tax or taxes or fiscal obligations," "revenues or budget or finance" } \\
\text { and "waqf" in investigating the rules on revenues and waqf. The findings in } \\
\text { this study are classified into five kinds of countries, namely countries that } \\
\text { highlight government revenue and waqf in the constitution, countries that } \\
\text { claim to recognize sharia law as the basis of the law but the waqf rules in the } \\
\text { constitution are missing, countries that mention in their constitution that gov- } \\
\text { ernment revenues are placed under the government system, financial system, } \\
\text { and parliament, countries that place waqf is ruled under the public finance } \\
\text { matter, and countries that place waqf as the main policy. This finding implies } \\
\text { that the constitutional rules lead to the view that waqf is a part of public fi- } \\
\text { nance that can be used as a fiscal policy tool and should be included in the } \\
\text { state budget plan. }\end{array}$ \\
\hline
\end{tabular}

(02021; This is an Open Access Research distributed under the term of the Creative Commons Attribution License (https://Creativecommons.org/licences/by/4.0), which permits unrestricted use, distribution, and reproduction in any medium, provided the original works is properly cited.

\section{INTRODUCTION}

In general, public finance studies the government's role in the economy. In fulfilling the role, the government needs to manage the budget. There is a way to collect sources of revenues and allocate the available resources. The revenues which are imposed on the economic agents are expected to affect the available resources for spending and savings. At the same time, the allocation affects the demand for public goods and services. Therefore, the research on public finances will look at many issues, such as the effective allocation of available capital, income distribution to people, and economic stability. 
Public finance experts have long understood that funding is the foundation of public entities. Some studies suggest that the government should be looking for revenues first before they spend. For example, ${ }^{1}$ believe that government revenues have a more influential role than government expenditures in controlling the economy. It shows that a revenue base plan is essential to meet the needs for public goods and services. Understanding the revenue base and its structure is essential to examine how much flexibility a government has in planning the needed revenues from the various sources.

The rules in the constitution have already stated a standard list of revenues. It shows that the standard list has a long story. Scholars, for example, ${ }^{2}$ also agree on the type of each revenue that can be collected and expended by the government. One of these revenues is waqf. As mentioned in, ${ }^{3}$ it has been recognized as part of Islamic civilization. Their roles in providing public goods have also been recognized since the early days of Islam until now. However, scholars such as ${ }^{4}$ have not agreed yet that waqf can be considered as government revenues. In this paper, we will argue from constitutional rules that waqf is one of the types of government revenues and has become an essential matter in public finance. These findings will oppose those who argue that waqf as social finance matters.

This study will use the legal basis in deriving the subject matters of waqf as a new sub-field in public economics. This study aims to examine the effect of both constitutional rules and levels of government on fiscal policy results. The organization of this study will be divided into five sections. Section two will discuss the history of government revenues. The discussion will also highlight the purpose and principles of revenues. Section three will try to look at the constitutional rules in a sample of countries under the Organization of Islamic Countries (OIC). Section four will discuss the effect of both constitutional rules and level of government on the fiscal policy results. Section five provides conclusions.

\section{RESEARCH METHOD}

The constitutional rules concerning revenues have been widely accepted and frequently discussed that any further discussion tends to be repetitious. However, it is impossible to appreciate the relation of the uniformity rules to the current practices of the taxing powerfully without some consideration of their function as it relates to this type of tax and the Shariah law that government revenues are linked to. Therefore, this section tries to look at the constitutional rules on both subjects in a sample of countries under the Organization of Islamic Countries (OIC). The selection of

Tsangyao Chang and Gengnan Chiang, "Revisiting the Government Revenue-Expenditure Nexus: Evidence from 15 OECD Countries Based on the Panel Data Approach," Czech Journal of Economics and Finance (Finance a Uver) 59, no. 2 (2009): 165-72.; Iulia Rosoiu, "The Impact of the Government Revenues and Expenditures on the Economic Growth," Procedia Economics and Finance 32 (2015): 526-33.

2 Chang and Chiang, "Revisiting the Government Revenue-Expenditure Nexus: Evidence from 15 OECD Countries Based on the Panel Data Approach."; Konstantinos Angelopoulos, James Malley, and Apostolis Philippopoulos, "Tax Structure, Growth, and Welfare in the UK," Oxford Economic Papers 64, no. 2 (2012): 237-58.

3 Muhammad Zubair Abbasi, "The Classical Islamic Law of Waqf: A Concise Introduction," Arab Law Quarterly 26, no. 2 (2012): 121-53.

4 Miriam Hoexter, "Waqf Studies in the Twentieth Century: The State of the Art," Journal of the Economic and Social History of the Orient 41, no. 4 (1998): 474-75.; Azni Hartini Azrai Zaimi Ambrose, Mohamed Aslam Gulam Hassan, and Hanira Hanafi, “A Proposed Model for Waqf Financing Public Goods and Mixed Public Goods in Malaysia," International Journal of Islamic and Middle Eastern Finance and Management 11, no. 3 (2018): 395-415, https://doi.org/10.1108/IMEFM-01-2017-0001. 
this sample is based on three main reasons. First, the sample is also a member of the Islamic Development Bank. It may provide essential findings that look at the aspect of public finance matters for intervention purposes. Second, it provides additional practices to link between constitutional rules and taxes. Third, the shariah law may provide an additional list of government revenues.

The sample is compiled from the website (https://www.constituteproject.org/?lang=en) of the Comparative Constitutions Project. The list of samples is presented in column 1 of Table 1. It covers fifty-nine countries that historically enjoy a different law origin. The sample has also gone through several amendments, but it is only reported the recent amendments. The authors manage to only use the draft version for three countries, namely Libya, Syria, and Yemen.

Then we choose the keywords which can analyze and discriminate rules in our sample. The most effective conditions, with reduced capacity to identify potentially significant rules for our sample, are "tax or taxes or fiscal obligations" (hereafter taxes) and "revenues or budget or finance". (hereafter revenues), "waqf" (or similar words such as wakf or endowment". This search yields all countries, with the taxes being mentioned in the constitution, except in Syria.

\section{ANALYSIS AND DISCUSSION}

\section{Historical Perspective of Government Revenues and Law Origin}

This section will discuss the history of government revenues. The discussion will also highlight the purpose and principles of revenues. The history will be chronologically discussed in an attempt to conclude that revenues are related to the origin of law.

The presentation of the government budget and fiscal policy was initiated by Sir Robert Walpole ${ }^{5}$ who acted as Chancellor of the Exchequer of England in 1720. It was followed by other countries that follow the Westminster Parliamentary System. For example, in Malaysia, the first sitting of parliament was held in 1959, and the finance minister presented the annual budget for the coming year. The minister is responsible for setting revenues and public spending across the nation and announces changes to these each year in the annual Budget statement.

It shows that the government acquires the resources to finance its spending through several different methods. In certain instances, taxation is the most relevant. Most countries raise resources through a range of taxation, including direct taxes on income and property income. Several indirect taxes such as charges on licenses and permits, service fees, interest and return on investments, sales and leasing of government facilities, fines and penalties, and non-revenue receipts comprise all refunds of expenditure and receipts from other government departments.

While taxation has a long history, in ancient times, it played a relatively minor role. During the Greece Era (700-400 BC), taxes on consumption and imported goods were two essential revenues. Other taxes, such as taxes on the property, were imposed temporarily as additional revenue to finance the war. However, during the early Roman (27 B.C.-286 AD), the list of taxes was extended to other assets such as real estate (mainly land). The taxes (known as head tax) were also differently imposed for free citizens and slaves between nationals and residents of conquered territories.

5 Hubert Hall, "The Sources for the History of Sir Robert Walpole's Financial Administration," Transactions of the Royal Historical Society 4 (1910): 33-45, https://doi.org/https://doi.org/10.2307/3678383. 
The ancient tax system was also adopted by other provinces, such as Persia (550 BC - 651 AD) and Egypt (3100 B.C.-332B.C). The provinces relied on their revenues on head taxes and land taxes. In addition, the land tax was revised to establish a clear relation with the productivity of the soil, or a 10th of the produce was collected as a tax in kind (or famously known as the tithe). The inheritance tax was also introduced, but the charges were exempted for close relatives of the deceased person.

The middle ages or medieval period that covers eleven decades (from the 5 th to the 15 th century) inherit the tax system during the Roman Empire. The tax system was also part the European history. Many jurisdictions in Europe adopted this system. The direct taxes are directed towards a variety of obligatory services (such as free education and health) and a system of "aid" (such as humanitarian aids and official development assistance). In contrast, indirect taxes were introduced for transit duties and market fees. They were a charge on goods and services that pass through a particular jurisdiction. The indirect taxes on certain foods and beverages were partly paid by consumers and partly by producers and residents.

Today, as stated in, ${ }^{6}$ the list of taxes covers income tax, goods and services tax, duty excises, and import tariffs, tourism tax, tax incentives, tax credits, and investment allowances, accelerated depreciation, accelerated depreciation, indirect tax incentives, and investment subsidies. The composition of tax revenues creates conflicting theories. The central issues are on the subject matters, efficiency, and equity. The tax should be levied on wages concerning consumption and under-consumption, and the sales tax against the domestic export tax. The efficiency may raise on whether the tax enhances or diminishes the overall welfare of taxpayers. In contrast, the equity issue concerns the fairness of tax to everybody.

The theory suggests that the tax on income leads to a higher welfare (efficiency) cost than taxing consumption. Since income tax, which includes both labour and capital tax components, limits the opportunity of the taxpayer to save. However, ${ }^{7}$ argue that this theory is doubtful. The taxpayer planning and the accumulation of human and physical capital involve time and cost, respectively. Hence, both variables play a crucial role. The welfare costs of both taxes on income and consumption are uncertain.

The choice between earnings taxation and consumption taxation creates another issue. Its impact is on equity. Taxing consumption, which is traditionally more regressive, hits much harder the poor than the rich. However, the impact is also doubtful. Authors such as ${ }^{8}$ said that the impact is exaggerated. Therefore, efforts to address this issue through initiatives such as graduated consumption taxes would be ineffective and administratively unworkable.

6 Alvin Warren, "Would a Consumption Tax Be Fairer Than an Income Tax?," The Yale Law Journal 89, no. 6 (1980): 1081, https://doi.org/https://doi.org/10.2307/796024.; Chang and Chiang, "Revisiting the Government Revenue-Expenditure Nexus: Evidence from 15 OECD Countries Based on the Panel Data Approach."

7 Joseph E. Stiglitz, "Chapter 15 Pareto Efficient and Optimal Taxation and the New New Welfare Economics," Handbook of Public Economics 2 (1987): 991-1042, https://doi.org/https://doi.org/10.1016/S15734420(87)80010-1.; Angelopoulos, Malley, and Philippopoulos, "Tax Structure, Growth, and Welfare in the UK."

8 Warren, "Would a Consumption Tax Be Fairer Than an Income Tax?"; Joseph Cordes, Jon Hakken, and Rosemarie Nielsen, "Consumption Vs. Income Taxes: What Are The Comparative Advantages?," Proceedings of the Annual Conference on Taxation Held under the auspices of the National Tax Association-Tax Institute of America 83, no. 105-109 (1990). 
The tax on imports, as stated in, ${ }^{9}$ is expected to lead to more competition from foreign companies if the ratio is lowered. However, this effort is part of a trade liberalization program, which aims to reduce domestic industries' protection. However, the consequence of this effort is unavoidable. It also reduces tax revenues, which is also undesirable. The feasible solution under such circumstances is to increase domestic consumption taxes. It will compensate for the losses in revenues due to a reduction in tax on imports. A higher tax on income is considered a viable solution for both policy and administration. On the policy side, it will negatively affect investment. Returns on revenues are administratively less specific and less timely than changes in consumption tax.

The legally mandated taxes are further discussed in the form of constitutional rules ${ }^{10}$ prove that constitutional rules influence the composition of government revenues and spending. ${ }^{11}$ empirically test that both variables are closely related to economic growth.

The constitutional rules also provide the right of the citizen to a reasonable degree of basic needs. The aim is to safeguard the welfare of each citizen. Both economic growth and basic needs (later on, it is classified in human development) are two essential variables in the welfare state. Therefore, ${ }^{12}$ propose three variables (different types of tax revenues to GDP ratio, economic growth and human development index (that comprise several variables of basic needs) as a measurement to rank countries based on their social and economic development level.

The above discussion shows that taxes have been a significant discussion throughout history. Taxes have been formally disclosed as a component of government revenues; many jurisdictions decide that government revenues and expenditures are legally mandated in the constitution. It shows that tax policies are a result form lawmakers' decisions. Hence, taxes are very much related to law.

\section{Constitutional Rule on Government Revenues in Organisation of Islamic Countries}

As shown in the third column of Table 1, the rules on taxes are mentioned under different matters except in Sudan and Guinea Bissau. The tax rules are divided under four main matters into constitutions - fundamental rights and duties; legislative powers (or other similar terms such as Parliament, Assembly, Royalty or the People Majlis); the relationship between executive and legislative; and public finance (also economic principles). Panel A, Table 1 reports the tax rules in Afghanistan; Algeria; Azerbaijan; Burkina Faso, Oman; Qatar; and Somalia that is put under the subject of fundamental rights and duties of citizens. In Turkey, tax is considered a political right.

9 Vito Tanzi and Howell Zee, “Tax Policy for Developing Countries,” IMF Economic Issues 27 (2001).

10 T. Persson and G. Tabellini, Political Economics: Explaining Economic Policy (Cambridge: MIT Press, 2000); Alessandro Lizzeri and Nicola Persico, "The Provision of Public Goods under Alternative Electoral Incentives," American Economic Review 91, no. 1 (2001): 225-39.; Gian Maria Milesi-Ferretti, Roberto Perotti, and Massimo Rostagno, "Electoral Systems and Public Spending," The Quarterly Journal of Economics 117, no. 2 (2002): 60957.; Stefanie Egidy, "Proportionality and Procedure of Monetary Policy-Making," International Journal of Constitutional Law 19, no. 1 (2021): 285-308.; Assefa Fiseha, "Federalism, Development and The Changing Political Dynamics in Ethiopia," International Journal of Constitutional Law 17, no. 1 (2019): 151-76.

11 Shih Ying Wu, Jenn Hong Tang, and Eric S. Lin, "The Impact of Government Expenditure on Economic Growth: How Sensitive to the Level of Development?," Journal of Policy Modeling 32, no. 6 (2010): 804-17.; Masudul Hasan Adil, "Wagner's Hypothesis: An Empirical Verification," IIM Kozhikode Society \& Management Review 6, no. 1 (2017): 1-12.

12 Sorana Vatavu et al., "How Taxes Relate to Potential Welfare Gain and Appreciable Economic Growth," Sustainability 11, no. 15 (2019): 4094. 
In countries like Bahrain and Egypt (Panel B, Table 1), tax is considered as the primary constituent of society. From a broader perspective, the society that possesses the essential elements such as likeness, reciprocal awareness, differences, interdependence, cooperation, and conflict may create injustice and inequitable economic development. Taxes are imposed to achieve social justice.

Table 1: Tax Rules in the Constitution

\begin{tabular}{|c|c|c|}
\hline Subjects & & Name of Country \\
\hline $\begin{array}{l}\text { Panel A: Fundamental Rights } \\
\text { and Duties }\end{array}$ & : & $\begin{array}{l}\text { Afghanistan, Algeria, Azerbaijan, Burkina Faso, Oman, Qatar, Somalia, and } \\
\text { Turkey (political right) }\end{array}$ \\
\hline $\begin{array}{l}\text { Panel B: Basic Constituents } \\
\text { of Society }\end{array}$ & : & Bahrain, and Egypt \\
\hline $\begin{array}{l}\text { Panel C: Legislative Power } \\
\text { (Parliament or Assembly or } \\
\text { Majlis or Royalty) }\end{array}$ & : & $\begin{array}{l}\text { Bangladesh, Gabon, Guyana, Kazakhstan, Maldives, Morocco, Niger, Nige- } \\
\text { ria, Pakistan, Tajikistan, and Tunisia }\end{array}$ \\
\hline $\begin{array}{l}\text { Panel D: Relationship be- } \\
\text { tween executive and legisla- } \\
\text { tive }\end{array}$ & : & $\begin{array}{l}\text { Benin, Chad, Cameroon, Cote d Ivoire, Comoros, Djibouti, Mali, Senegal, and } \\
\text { Togo }\end{array}$ \\
\hline Panel E: Role of A State & : & Kyrgyz, Libya, and Mauritania \\
\hline Panel F: Public Finance & : & $\begin{array}{l}\text { Albania, Brunei, Gambia, Indonesia, Iran, Jordan, Kuwait, Lebanon, Malay- } \\
\text { sia, Mozambique, Palestine, Sierra Leone, Saudi Arabia, Suriname, Turkmen- } \\
\text { istan, Uganda, United Arab Emirates, and Uzbekistan }\end{array}$ \\
\hline
\end{tabular}

The legislative power to issue tax law, as reported in Panel C Table 1, happens in countries such as Bangladesh (which is also mentioned simultaneously under the matter of public finance), Gabon, Guyana, Kazakhstan, Maldives, Morocco, Niger, Nigeria, Pakistan, Tajikistan, and Tunisia.

Tax rules are also mentioned as a matter that shows the relationship between executive and legislative. As shown in Panel D, Table 1, countries in the African region such as Benin; Chad; Cameroon; Cote d Ivoire; Comoros; Djibouti; Mali; Senegal; Togo discuss the tax law under those matters. However, countries like Kyrgyz, Libya, and Mauritania (Panel E, Table 1) discuss the tax law as the role of a state.

Panel F Table 1 shows that tax in countries such as Albania; Brunei; Gambia; Indonesia; Iran; Jordan; Kuwait; Lebanon; Malaysia; Mozambique; Palestine; Sierra Leone; Saudi Arabia; Suriname; Turkmenistan; Uganda; United Arab Emirates; and Uzbekistan is legislated under the financial matters of public finance.

In summary, the constitution provides the uniformity of rules that require the citizens to transfer to the government part of their income or property. It is a matter of the citizens' duty and the power (or right) that is given to the government to impose, abolish, remit, alter, or regulate any tax. The substance, the rate, and the objectives and also those who are exempted from paying taxes, are also mentioned in the constitutions. In several countries, tax rules concern only legal issues, but they are not related to economic or financial issues. Decisions regarding the merits of different types of taxes, the number of taxable properties and their rates, for example, are not a matter of tax law; they are political processes, not legal proceedings.

Having discussed the tax rules in the constitution leads towards the provision of constitutional rules in relation to the government budget. Our analysis of the sample of fifty five countries under the OIC, as presented in table 2, shows that only eight countries highlight both government revenues and waqf in the constitution. Although some countries such as Bahrain, Comoros, Kuwait, Maldives, Oman, Qatar, Saudi Arabia, Somalia, and United Arab Emirates claim that they 
acknowledge Shariah law as the basis of legislation, the waqf rules in the constitution are missing. The constitution mentions government revenues under the title of financial matters, as in the case of Brunei, Gambia, Jordan, Malaysia, and Yemen. While Egypt, Libya, and Pakistan, the rules on government revenues are put under the ruling system, financial system, and the parliament, respectively. Waqf is discussed as a section of the constitution. In Brunei and Malaysia, waqf is ruled under the public finance matter. In the Gambia, the law on waqf is recognized in the section on the constitution and the laws. In Pakistan and Egypt, waqf should be promoted as principal policy; and public rights, freedoms, and duties. While in Jordan, the administration of waqf is given judicial power.

In general, the government was given authority on the following aspects. First, the revenues would come from various sources under the constitution, such as taxes, non-taxes and other receipts. However, countries such as Brunei, Libya, and Malaysia define that waqf as government revenues. In other countries, such as Egypt, Pakistan, and Yemen, the state is encouraged to establish the waqf administration. While in Gambia and Jordan, the constitution rules only say that these countries should create and develop the waqf administration under a specific law. Second, the constitutional rules in Brunei, Libya, and Malaysia states that a separate fund needs to be established for the waqf fund. Third, depending on the level of government, waqf in Malaysia, which follows the federal system, is owned by the State government.

Table 2: Constitutional Rules on Government Revenues and Waqf

\begin{tabular}{|c|c|c|c|c|}
\hline \multirow[t]{3}{*}{ Countries } & \multicolumn{4}{|c|}{ Constitutional Rules } \\
\hline & \multicolumn{2}{|c|}{ Government Revenues } & \multicolumn{2}{|l|}{ Waqf } \\
\hline & Article & Matters & Article & Matters \\
\hline Brunei & $\begin{array}{l}\text { Article } 58 \text { - All revenues and } \\
\text { sums of money be paid into a } \\
\text { "Consolidated Fund". }\end{array}$ & Finance & $\begin{array}{l}\text { Article } 69 \text { - The provisions shall not } \\
\text { be applicable to Muslim revenues } \\
\text { and funds }\end{array}$ & Finance \\
\hline Egypt & $\begin{array}{l}\text { Article } 124 \text { - The state budget } \\
\text { includes all of its revenue and } \\
\text { expenditure without } \\
\text { exception. }\end{array}$ & $\begin{array}{l}\text { The Ruling } \\
\text { System }\end{array}$ & $\begin{array}{l}\text { Article } 90-\text { The state shall } \\
\text { encourage the charitable } \\
\text { endowment system }\end{array}$ & $\begin{array}{l}\text { Public Rights, } \\
\text { Freedoms, and } \\
\text { Duties }\end{array}$ \\
\hline Gambia & $\begin{array}{l}\text { Article } 236(1)-\text { the revenue } \\
\text { sources for the government } \\
\text { shall be clearly defined }\end{array}$ & $\begin{array}{l}\text { Public } \\
\text { Finance }\end{array}$ & $\begin{array}{l}\text { Article } 9(1)(e) \text { - laws of the Gambia } \\
\text { consist of the Shari'ah as regards } \\
\text { matters of marriage, divorce, burial, } \\
\text { endowment (waqf), and inheritance }\end{array}$ & $\begin{array}{l}\text { The } \\
\text { Constitution } \\
\text { and the Laws }\end{array}$ \\
\hline Jordan & $\begin{array}{l}\text { Article } 115 \text { - All receipts from } \\
\text { taxes and other state's } \\
\text { revenues should be paid into } \\
\text { the Treasury }\end{array}$ & $\begin{array}{l}\text { Financial } \\
\text { Matters }\end{array}$ & $\begin{array}{l}\text { Article } 107 \text { - the affairs of the } \\
\text { Islamic (Waqfs) and the } \\
\text { administration of their financial and } \\
\text { other matters, shall be specified by a } \\
\text { particular law }\end{array}$ & Judicial Power \\
\hline Libya & $\begin{array}{l}\text { Article } 176 \text { - revenues shall be } \\
\text { delegated to the Public } \\
\text { Treasury }\end{array}$ & $\begin{array}{l}\text { The } \\
\text { Financial } \\
\text { System }\end{array}$ & $\begin{array}{l}\text { Article } 31-\text { The religious } \\
\text { endowments (awqaf) shall enjoy } \\
\text { their sanctity and shall not be mixed } \\
\text { with State funds. }\end{array}$ & $\begin{array}{l}\text { Form and } \\
\text { Fundamental } \\
\text { Pillars of the } \\
\text { State }\end{array}$ \\
\hline Malaysia & $\begin{array}{l}\text { Article } 97(1)-\text { revenues and } \\
\text { sums of money received by } \\
\text { the Federation shall be paid to } \\
\text { Federal Consolidated Fund. }\end{array}$ & $\begin{array}{l}\text { Financial } \\
\text { Matters }\end{array}$ & $\begin{array}{l}\text { Article } 97(3)-\text { Zakat, Fitrah, } \\
\text { Baitulmal (including waqf) or } \\
\text { similar Islamic religious revenue } \\
\text { shall be paid into a separate fund }\end{array}$ & $\begin{array}{l}\text { Financial } \\
\text { Matters }\end{array}$ \\
\hline Pakistan & $\begin{array}{l}\text { Article } 78 \text { - revenues received } \\
\text { by the Federal Government } \\
\text { shall form part of the Federal } \\
\text { Consolidated Fund. }\end{array}$ & $\begin{array}{l}\text { The } \\
\text { Parliament }\end{array}$ & $\begin{array}{l}\text { Article } 31-\text { The State shall } \\
\text { endeavour to secure the proper } \\
\text { organization of zakat ushr, auqaf } \\
\text { and mosques }\end{array}$ & $\begin{array}{l}\text { Principle } \\
\text { Policy }\end{array}$ \\
\hline
\end{tabular}




$\begin{array}{llll}\text { Yemen } & \begin{array}{l}\text { Article } 374-\text { The public Public } \\ \text { budget shall include revenue Finance } \\ \text { estimates and detailed } \\ \text { projected expenditures }\end{array} & \begin{array}{l}\text { Article } 29-\text { The State shall promote } \\ \text { endowments }\end{array} & \begin{array}{l}\text { General } \\ \text { Foundation }\end{array} \\ \end{array}$

\section{Fiscal Policy Outcomes}

Its authority under constitutional rules limits the government's right to control waqf. This power is the legislative, not the executive and not the judiciary in a parliamentary system. In many countries, the legality of waqf has been affirmed by constitutional rules, including Brunei, Egypt, Gambia, Jordan, Libya, Malaysia, Pakistan, Singapore (an example of counties outside OIC, refer to $^{13}$ and Yemen. At the same time, the right to administer waqf and determine the beneficiaries it owes is a legislative power privilege. The executive power is responsible for administering waqf law. The administration of the waqf fund is generally separated into different accounts because waqf differs so significantly in their types of property to be endowed and the beneficiaries that can be derived from the endowed properties. Therefore, further analysis is needed to address the issues behind the fiscal policy implication of constitutional rules on waqf.

Fiscal policy is specifically designed to achieve particular economic objectives by appropriately setting various fiscal policy instruments, such as tax rates, revenue, and spending. The relation between specific instruments and objectives is frequently disputed, and the advisability of 'fine-tuning' is questioned. However, the tools necessary to achieve the objectives of the policy approach are generally accepted. In explaining this approach, we will discuss the revenues as instruments and the working of fiscal policy in the presence of waqf.

Instruments - Waqf property (or mawqoof) can be in the form of in-kind or cash. Both can be categorized as revenue receipts depending on the nature of waqf property. By preserving the perpetuity of waqf property, the proceeds of profit and dividend can be transferred into the Baitulmal Fund as revenue receipt. A separate account from the State Consolidated Fund and both accounts may also comprise revenue receipts and capital receipts. However, the waqf property may be disposed of temporarily, as in the case of istibdal waqf.

While capital receipts such as istibdal waqf, proceeds from the sale of waqf property (i.e., disinvestment), do not give rise to the debt. However, both receipts may increase government revenues if waqf property works well. It starts in a government trust fund. A government trust is established as a legal entity (a government agency or mutawwali) to hold waqf property for a person and managed by nadhir, a neutral third party. Trust funds can hold various waqf properties such as money, real property, shares, Sukuk or a combination of many different types of properties or assets.

Then, how does it work? Three key parties comprise a government trust fund - mutawwali (sets up a trust and holds it with their properties or assets), beneficiary (a person selected to receive the benefits that are generated from waqf properties), and nadhir (charged with managing the properties in the trust). The key motivations of this fiscal instrument are for a mutawalli to (i) create a vehicle that sets terms for the way properties or assets are to be held, gathered, or distributed in the future; and (ii) create mutual cooperation (or ta'awun) where a nadhir acts in the

13 Abdul Ghafar Ismail, Muhammad Hasbi Zaenal, and Muhammad Hakimi Mohd Shafia, Philanthropy in Islam: A Promise to Welfare Economics System (Islamic Research and Training Institute, 2014). 
sole interest of the waqif (special waqf or waqf ahli) or other people in general (general waqf or Waqf Khayri).

Working of Fiscal Policy. The government may start economic planning by planning a yearly budget, which becomes part of a medium-term development plan. The budget plan is the operational phase of the development plan (hereafter, we refer to both as the budget plan). Over the years, changes have been made to both the scope of the budget plan and the involvement of government agencies (such as waqf institutions). Baitulmal funds that comprise revenue receipt, capital receipt, and trust funds have appeared as an essential element of the involvement of the waqf agency for budget planning. This element does not exist before.

The planning for expenditure is determined by the estimated revenues of the budget plan. The government's total revenues consist of estimated revenue receipts (waqf benefits), capital receipts, and trust funds (the original amount of waqf). The revenues from waqf funds are separated from the consolidated state revenues. The state revenue receipts comprise both tax and non-tax revenue but also waqf benefits.

The current practice is to spend all the state revenues, while the estimated non-plan expenditure is known as Balance from Current Revenue (BCR). On the other hand, the estimated capital receipts may be divided into debt capital receipts and non-debt capital receipts. The latter is also called Miscellaneous Capital Receipt (MCR) after a deduction from the estimated non-plan capital expenditure. The government may also use borrowing to finance the planned budget.

The three variables are BCR, the MCR, and the fiscal deficit to determine the Gross Budgetary Support (GBS) size for the budget plan. Suppose a country has a federal system, a portion of the total GBS shall be provided to the state as a federal grant. The government-linked companies (GLC) also transfer some resources in the form of a dividend.

Having planned the budget, the next step is to have a list of budget programs. In this study, we propose an example of a social security program promoting policies and helping all members of society to have adequate levels of social safeguarding. The safeguarding includes access to health care and income security, in particular in elderly care facilities, unemployment benefits, health bills, disability, daily child care, maternity, or breastfeeding facilities.

\section{CONCLUSION}

In this study, the findings show that constitutional rules give the power to the government to extend the list of revenues that includes waqf. It shows that waqf is legislated under the constitution as financial matters or public finance. It implies that waqf belongs to the government, and the executive must incorporate waqf in the state budget plan. The results show that constitutional rules lead to the more significant role of waqf and subsequently an impactful of waqf as the instrument of public policy. Hence, the author suggest that the constitutional rules lead to the view that waqf is a part of public finance that can be used as a fiscal policy tool should be included in the state budget plan.

\section{REFERENCES}

Abbasi, Muhammad Zubair. "The Classical Islamic Law of Waqf : A Concise Introduction.” Arab Law Quarterly 26, no. 2 (2012): 121-53. 
Adil, Masudul Hasan. "Wagner's Hypothesis: An Empirical Verification.” IIM Kozhikode Society \& Management Review 6, no. 1 (2017): 1-12.

Ambrose, Azni Hartini Azrai Zaimi, Mohamed Aslam Gulam Hassan, and Hanira Hanafi. "A Proposed Model for Waqf Financing Public Goods and Mixed Public Goods in Malaysia." International Journal of Islamic and Middle Eastern Finance and Management 11, no. 3 (2018): 395-415. https://doi.org/10.1108/IMEFM-01-2017-0001.

Angelopoulos, Konstantinos, James Malley, and Apostolis Philippopoulos. "Tax Structure, Growth, and Welfare in the UK." Oxford Economic Papers 64, no. 2 (2012): 237-58.

Chang, Tsangyao, and Gengnan Chiang. "Revisiting the Government Revenue-Expenditure Nexus: Evidence from 15 OECD Countries Based on the Panel Data Approach." Czech Journal of Economics and Finance (Finance a Uver) 59, no. 2 (2009): 165-72.

Cordes, Joseph, Jon Hakken, and Rosemarie Nielsen. "Consumption Vs. Income Taxes: What Are The Comparative Advantages?" Proceedings of the Annual Conference on Taxation Held under the Auspices of the National Tax Association-Tax Institute of America 83, no. 105-109 (1990).

Egidy, Stefanie. "Proportionality and Procedure of Monetary Policy-Making." International Journal of Constitutional Law 19, no. 1 (2021): 285-308.

Fiseha, Assefa. "Federalism, Development and The Changing Political Dynamics in Ethiopia." International Journal of Constitutional Law 17, no. 1 (2019): 151-76.

Hall, Hubert. "The Sources for the History of Sir Robert Walpole's Financial Administration." Transactions of the Royal Historical Society 4 (1910): 33-45. https://doi.org/https://doi.org/10.2307/3678383.

Hoexter, Miriam. "Waqf Studies in the Twentieth Century: The State of the Art." Journal of the Economic and Social History of the Orient 41, no. 4 (1998): 474-75.

Ismail, Abdul Ghafar, Muhammad Hasbi Zaenal, and Muhammad Hakimi Mohd Shafia. Philanthrophy in Islam: A Promise to Welfare Economics System. Islamic Research and Training Institute, 2014.

Lizzeri, Alessandro, and Nicola Persico. "The Provision of Public Goods under Alternative Electoral Incentives.” American Economic Review 91, no. 1 (2001): 225-39.

Milesi-Ferretti, Gian Maria, Roberto Perotti, and Massimo Rostagno. "Electoral Systems and Public Spending." The Quarterly Journal of Economics 117, no. 2 (2002): 609-57.

Persson, T., and G. Tabellini. Political Economics: Explaining Economic Policy. Cambridge: MIT Press, 2000.

Rosoiu, Iulia. "The Impact of the Government Revenues and Expenditures on the Economic Growth." Procedia Econimics and Finance 32 (2015): 526-33.

Stiglitz, Joseph E. "Chapter 15 Pareto Efficient and Optimal Taxation and the New New Welfare Economics." Handbook of Public Economics 2 (1987): 991-1042. https://doi.org/https://doi.org/10.1016/S1573-4420(87)80010-1.

Tanzi, Vito, and Howell Zee. "Tax Policy for Developing Countries.” IMF Economic Issues 27 (2001).

Vatavu, Sorana, Oana Ramona Lobont, Petru Stefea, and Daniel Brindescu Olariu. "How Taxes Relate to Potential Welfare Gain and Appreciable Economic Growth." Sustainability 11, no. 
15 (2019): 4094.

Warren, Alvin. "Would a Consumption Tax Be Fairer Than an Income Tax?" The Yale Law Journal 89, no. 6 (1980): 1081. https://doi.org/https://doi.org/10.2307/796024.

Wu, Shih Ying, Jenn Hong Tang, and Eric S. Lin. "The Impact of Government Expenditure on Economic Growth: How Sensitive to the Level of Development?" Journal of Policy Modeling 32, no. 6 (2010): 804-17. 